\title{
Competitiveness Development Strategy in Textile Industry Center of Cigondewah Bandung, Indonesia
}

\author{
Taufiqurrahman Baso ${ }^{1}$, Yuhana Astuti ${ }^{2}$ \\ Telkom University, Faculty of Economics and Business, Telekomunikasi Street, Bandung 40257, West Java, Indonesia
}

\begin{abstract}
Competitiveness is the key to the growth of national economy to face AEC 2015. Therefore, it is necessary to increase competitiveness, especially to develop the Small and Medium Enterprises (SMEs) sector. This research aims to develop strategies for the competitiveness of SME businesses, in the Textile Industry Center of Cigondewah. This type of research used is descriptive research with mixed method design. Data collection was conducted through interviews, observations, questionnaires, documentation and literature studies. The informants of this research are SMEs in Textile Industry Center of Cigondewah and the authorities of Textile Industry Center of Cigondewah who understand the intricacies of Textile Industry Center of Cigondewah from the internal and external environment. The techniques of analysis used are IFE matrix, EFE matrix, SWOT matrix and QSPM matrix. The SWOT matrix is based on the EFE matrix that analyzes the opportunities and threats that come from outside the industry and IFE matrix which analyzes the strengths and weaknesses of the industry. While the QSPM matrix is used to prioritize alternative strategies the SWOT matrix obtains. The strategy is a top priority for the Textile Industry Cigondewah based on the analysis QSPM is to increase promotional efforts through various media and infrastructure improvements in cooperation with government agencies. In other words, the strategy adopted is a significant market penetration of SMEs seek greater market share through marketing efforts better. The strategy as a top priority for Textile Industry Center of Cigondewah based on the analysis of QSPM is to increase promotional efforts through various media and infrastructure improvements in cooperation with government agencies. In other words, the strategy adopted is a market penetration which means that SMEs seek greater market share through better marketing efforts.
\end{abstract}

Keywords: Industry Center, IFE, EFE, SWOT, QSPM

\section{Introduction}

The ASEAN Economic Community (AEC) in 2015 brings an opportunity and a challenge for the economy in Indonesia. With the enactment of AEC at the end of 2015, the countries belonging to the ASEAN members will experience flow in the form of a free market in the form of goods, services, investment and labor to and from each country.

Through MEA, integration will occur in the form of "free trade area", the elimination of trade tariffs among ASEAN member countries, as well as labor market and free capital markets, which will greatly affect the economic growth and development of each country. To face the era of AEC 2015, businesses in Indonesia would have to take strategic steps in order to face the competition with other ASEAN member countries, including the Micro, Small, and Medium Enterprises (MSMEs).

Starting from the year 2012, the number of SMEs in Indonesia is $56,534,592$ units of businesses and employs a workforce of $107,657,509$ people and contributed to the GDP (Gross Domestic Product) of 59.08\%. While at the provincial level, the largest population of SMEs in West Java, which is more than 9,000,000 units. MSMEs in West Java is able to absorb $97 \%$ of the workforce and contribute to over $60 \%$ of GRDP (Gross Regional Domestic Product) of West Java. ${ }^{[1]}$

Development of SMEs is not only carried out by SMEs, but also must be supported by all stakeholders. Support is expected to come from business associations, universities, and related institutions. The government's policy is also needed to encourage the development of SMEs ${ }^{[2]}$. The involvement of stakeholders is very influential on the successful development of SMEs in the Industry centers. The role and involvement of all stakeholders develop in accordance with their outlook and government policy towards SMEs. ${ }^{[3]}$

Broadly speaking, some options of strategies that can be done to develop SMEs including: (1) ease of access to capital; (2) infrastructure development assistance; (3) development of business scale; (4) development of business networks, marketing and business partnership; (5) development of human resources; (6) increase of access to technology; and (7) creation of more conducive business climate. ${ }^{[4]}$

Bandung as one of the biggest cities in West Java has a lot of economic potential, especially in the SME sector. Bandung city currently has seven regional centers of industry and trade that could potentially be a business center as well as tourist attractions of world-class industry in the future. The seven regional industry centers are Knitting Industry Center of Binongjati, Textile Industry Center of Cigondewah, Cihampelas Jeans Industry Center, Industry Center of Suci T-Shirt, Shoe Industry Center of Cibaduyut, Industry Center of Tofu and Tempe Cibuntu, and Industry Center of Dolls at Sukamulya Sukajadi. ${ }^{[5]}$

One SME that is being developed as an industry center in the city of Bandung is Textile Industry Center of Cigondewah in Bandung Kulon Sub-district, Cigondewah Kaler Village, Cigondewah Kidul Village, and Cigondewah Rahayu Village. The industry centers focus on producing various kinds of materials such as fabrics for garments, bags, hats, dolls and so on. The Textile Industry Center of Cigondewah has the potential to improve the economy in Indonesia, especially in facing AEC 2015. The potential of

\section{Volume 4 Issue 11, November 2015}




\section{International Journal of Science and Research (IJSR) \\ ISSN (Online): 2319-7064}

Index Copernicus Value (2013): 6.14 | Impact Factor (2014): 5.611

the Textile Industry Center of Cigondewah can be seen in Table 1. ${ }^{[6]}$

Table 1: The potential of the Textile Industry Center of

\begin{tabular}{|c|c|}
\multicolumn{2}{c}{ Cigondewah } \\
\hline Potentials & Total \\
\hline Business Units & 313 \\
\hline Business Focus & $\begin{array}{c}\text { Production of various types of } \\
\text { fabric or cloth }\end{array}$ \\
\hline Work Force & 567 \\
\hline Investment turnover/day & $\operatorname{Rp~401,650,000}$ \\
\hline
\end{tabular}

According to the Head of Department of Cooperatives, Small and Medium Industry Trade Bandung, Ema Sumarna, there are common problems inhibiting the development of Industry centers in Bandung. Textile Industry Center of Cigondewah has common problems including narrow roads and parking lots as well as the unavailability of PSU (Public Service Units) and TIU (Technical Implementation Units). ${ }^{[7]}$

Under the conditions described above, Textile Industry Center of Cigondewah has a role and strategic potential, but there are still some problems that could hinder the development of the Industry centers. Obviously, efforts to develop the Industry center are currently very necessary. Development efforts must be accompanied by a new, more appropriate strategy for mapping the actual targets to be achieved. Such efforts can be done by analyzing the strengths and weaknesses found in the internal environment of the Industry centers, as well as identifying the threats and opportunities that come from the external environment of the Industry centers. Therefore, Textile Industry Center of Cigondewah can optimize opportunities and minimize the threats that exist to deal with AEC 2015. Based on this argument, the researchers are working to develop a proper development strategy for the Textile Industry Center of Cigondewah especially in facing AEC 2015.

This research aims to develop a business strategy of competitiveness of SMEs in the Textile Industry Center of Cigondewah, particularly in facing the ASEAN Economic Community by 2015. The technique of analysis used is analysis of external and internal factors of the Industry center as the basis in analyzing the opportunities and threats that come from outside of the Industry center and see the strengths and weaknesses that come from the Industry center. The variables to be studied to determine the external and internal factors of the company are analyzed by using EFE and IFE matrix. Afterwards, the researchers use a SWOT analysis to develop an alternative strategy for the Textile Industry Center of Cigondewah based on the external and internal factors that have been analyzed by using EFE and IFE matrix. After that QSPM matrix is used to prioritize the best alternative strategy derived from the SWOT matrix.

\section{Basic Theories}

Strategic management can be defined as the art and science in formulating, implementing, and evaluating decisions that can help the organization achieve its goals ${ }^{[8]}$. The formulation of the strategy is the development of long-term plans to achieve company objectives by taking into account the opportunities and threats that come from the company environment, as well as the strengths and weaknesses of the company. ${ }^{[9]}$

Techniques of strategy formulation can be integrated into the framework of the three stages of decision making. Such a device is shown in a framework that can be applied to all sizes and types of organizations and can help strategists identify, evaluate, and select strategies. ${ }^{[8]}$

Stage 1 or Input Stage consists of External Factors Evaluation (EFE) Matrix, Internal Factors Evaluation (IFE) Matrix, and Competitive Profile Matrix (CPM). This stage contains the basic information needed to formulate strategies.

Stage 2 or Matching Stage focuses on the creation of an alternative strategy that makes sense to take into account the major internal and external factors. The techniques of Phase 2 include the Strengths-Weaknesses-Opportunities-Threats (SWOT) Matrix, Strategic Position and Action Evaluation (SPACE) Matrix, Boston Consulting Group (BCG) Matrix, Internal-External (IE) Matrix, and the Great Strategy Matrix that can be used with any sequence.

Stage 3 or Decision Stage involves a technique that is only Quantitative Strategic Planning Matrix (QSPM). QSPM uses input information from Stage 1 to objectively evaluate the alternative strategies identified in Stage 2. QSPM shows the relative attractiveness of various alternative strategies and thus, provide the objective basis for the selection of alternative strategies. ${ }^{[5]}$

The initial stage is the first stage of the strategy formulation process. At this stage a summary of the basic information needed to formulate strategies is made. The input stage uses 2 matrix, the matrix of External Factor Evaluation (EFE), which generate opportunities and threats and Internal Factor Evaluation (IFE) Matrix which produce strengths and weaknesses. The next stage is matching stage. Matching stage is the determinant factor for external and internal success as the effective key to produce a viable alternative strategy that is derived from the SWOT matrix. Then the the last stage is making decisions of the best alternative strategy using QSPM matrix based on the analysis of IFE, EFE, and SWOT matrix.

\section{Findings and Discussion}

\subsection{Research Informants}

The informants in this study are the ones who are competent in their field and know the ins and outs of the Textile Industry Center of Cigondewah, i.e. the coordinator of the Textile Industry Center of Cigondewah, Department of Cooperatives, SMEs, Trade and Industry, the city of Bandung, as well as the SMEs entrepreneurs in the Textile Industry Center of Cigondewah.

\subsection{EFE and IFE Matrix}

The external factors which could become opportunities and threats based on the analysis of the external environment 


\section{International Journal of Science and Research (IJSR) \\ ISSN (Online): 2319-7064 \\ Index Copernicus Value (2013): 6.14 | Impact Factor (2014): 5.611}

that has been done previously are used in the EFE matrix to be given weight and rating to determine scores for each of these external factors. The assessment of external factors is made in the form of a matrix table. The matrix table is filled by the informants who are experts and know the ins and outs of the Industry centers in the fields of internal and external Textile Industry Center of Cigondewah. Based on the analysis of the external environment assessment on the Textile Industry Center of Cigondewah that has been conducted by the researchers, the EFE matrix of the Textile Industry Center of Cigondewah can be described in table 2:

Table 2: EFE Matrix

\begin{tabular}{|l|c|c|c|}
\hline \multicolumn{1}{|c|}{ External Factors } & Weight & Rating & $\begin{array}{c}\text { Weight } \\
\text { Score }\end{array}$ \\
\hline \begin{tabular}{l} 
Opportunities \\
\hline $\begin{array}{l}\text { 1) The support of the surrounding } \\
\text { community }\end{array}$
\end{tabular} & 0.1 & 4 & 0.4 \\
\hline $\begin{array}{l}\text { 2) The government's policy to } \\
\text { encourage the development of } \\
\text { Industry Center }\end{array}$ & 0.13 & 3 & 0.39 \\
\hline 3) Availability of internet technology & 0.11 & 3 & 0.33 \\
\hline $\begin{array}{l}\text { 4) Hereditary business culture in } \\
\text { Cigondewah }\end{array}$ & 0.06 & 4 & 0.24 \\
\hline 5) The opening of broader market share & 0.12 & 3 & 0.36 \\
\hline 6) Changes in people's lifestyles & 0.09 & 2 & 0.18 \\
\hline 7) Availability of credit offer for SMEs & 0.08 & 2 & 0.16 \\
\hline Total Score of Opportunities & & & $\mathbf{2 . 0 6}$ \\
\hline Threats & 0.09 & 2 & 0.18 \\
\hline 1) Continuous rise of Inflation & 0.05 & 3 & 0.15 \\
\hline 2) Expensive tax rate & 0.06 & 3 & 0.18 \\
\hline 3) Competition of similar industries & 0.11 & 2 & 0.22 \\
\hline $\begin{array}{l}\text { 4) Decline in people's purchasing } \\
\text { power }\end{array}$ & & & $\mathbf{0 . 7 3}$ \\
\hline Total Score of Threats & $\mathbf{1 . 0 0}$ & & $\mathbf{2 . 7 9}$ \\
\hline TOTAL
\end{tabular}

Based on the results of calculations of the EFE matrix, it is clear that The government's policy to encourage the development of Industry Center with a score of 0.39 can be a major factor for development opportunities of Cigondewah Industry Center. Meanwhile, weak purchasing power, with the score 0.22 can be a major threat factor for the development of Industry Center of Cigondewah.

The total weight score of EFE matrix of the Textile Industry Center of Cigondewah is 2.79. This shows that SMEs in Industry Center of Cigondewah can respond to the opportunities and threats that are in the external environment with reasonably good Industry centers since the score obtained is above the average of the total score average, that is 2.5 .

Almost the same with EFE matrix, in the IFE matrix, the internal factors that can be the strengths and weaknesses based on those results of internal environmental analysis have been done previously used in the IFE matrix to be given the weight and rating to determine a score for each of the internal factors. Assessment of internal factors made in the form of a matrix table. The matrix table is filled by informants who are experts and know the ins and outs of the Industry centers in the fields of internal and external Textile Industry Center of Cigondewah.
Based on the analysis of internal environmental assessment of the Textile Industry Center of Cigondewah that has been conducted by researchers, the IFE matrix of the Textile Industry Center of Cigondewah can be described in Table 3:

Table 3: IFE Matrix

\begin{tabular}{|c|c|c|c|}
\hline Internal Factors & Weight & Rating & $\begin{array}{l}\text { Weight } \\
\text { Score }\end{array}$ \\
\hline \multicolumn{4}{|l|}{ Strengths } \\
\hline 1) Relatively cheaper price & 0.11 & 4 & 0.44 \\
\hline $\begin{array}{l}\text { 2) Smooth supply of raw materials and } \\
\text { meet consumer demand }\end{array}$ & 0.07 & 4 & 0.28 \\
\hline $\begin{array}{l}\text { 3) Good reputation in the eyes of } \\
\text { consumers }\end{array}$ & 0.05 & 4 & 0.2 \\
\hline 4) The range that covers national market & 0.06 & 3 & 0.18 \\
\hline 5) Availability of local labor & 0.05 & 3 & 0.12 \\
\hline \begin{tabular}{|c|} 
Total Score of Strengths \\
\end{tabular} & & & 1.22 \\
\hline \multicolumn{4}{|l|}{ Weaknesses } \\
\hline 1) Not having a cooperative & 0.13 & 1 & 0.13 \\
\hline $\begin{array}{l}\text { 2) SMEs do not yet have employees so } \\
\text { that everything is done by business } \\
\text { owners }\end{array}$ & 0.03 & 2 & 0.06 \\
\hline 3) Only using private sources of capital & 0.04 & 2 & 0.08 \\
\hline 4) Inadequate infrastructure & 0.15 & 1 & 0.15 \\
\hline 5) Less aggressive marketing & 0.11 & 1 & 0.11 \\
\hline 6) Not having a standardized product & 0.07 & 1 & 0.07 \\
\hline 7) Lack of product innovation & 0.06 & 2 & 0.12 \\
\hline $\begin{array}{l}\text { 8) Not to maximum utilization of TIU } \\
\text { by the entrepreneurs }\end{array}$ & 0.07 & 2 & 0.14 \\
\hline Total Score of Weaknesses & & & 0.86 \\
\hline TOTAL & & & 2.08 \\
\hline
\end{tabular}

Based on the analysis of IFE matrix, it is found that prices are relatively cheaper with a score of 0.44 becoming a major force possessed by the Textile Industry Center of Cigondewah. Meanwhile, inadequate infrastructure with a score of 0.15 becoming a major weakness which is owned by the Textile Industry Center of Cigondewah. The total weight score of the IFE matrix of the Textile Industry Center of Cigondewah is 2.08. This shows that SMEs in the Textile Industry Center of Cigondewah is still relatively low in terms of internal environment where SMEs of the Textile Industry Center of Cigondewah has not been able to maximize its strengths and to deal with the weaknesses that exist.

\subsection{SWOT matrix}

The SWOT matrix is based on the assessment of the internal environment (Strengths and Weaknesses) and the external environment (Opportunities and Threats) to maximize and leverage the strengths and the opportunities and eliminate weaknesses and avoid threats. At EFE matrix, the score of the opportunities is 2.06 and the threats is 0.73 , so the difference in scores of opportunities and threats is 1.33 . While the IFE matrix, scores and score for the strength is 1.22 and the weaknesses is 0.86 , so the score difference is 0.36 . The difference in the score is used to determine the coordinates and strategic direction which will be the main focus of the industry to respond to the external and internal environment of the industry at this time. The score difference of the strengths and weaknesses is the $\mathrm{X}$ value, while the score difference of opportunities and threats is $\mathrm{Y}$ 


\section{International Journal of Science and Research (IJSR) \\ ISSN (Online): 2319-7064}

Index Copernicus Value (2013): 6.14 | Impact Factor (2014): 5.611

value. The diagram of SWOT analysis can be described in Figure 1.

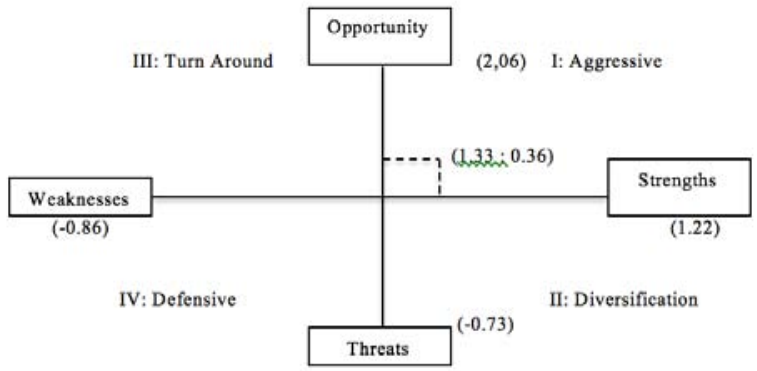

Figure 1: Diagram of SWOT Analysis
Figure 1 shows that the result of SWOT analysis is in the position of quadrant I, which finds that there are many opportunities from the external side and the strength from the internal side. Therefore, the Textile Industry Center of Cigondewah needs to implement policy strategies that support aggressive growth. It is necessary to devise SWOT matrix to formulate an alternative strategy to increase aggressive growth by leveraging the existing opportunities. The following SWOT matrix for Textile Industry Center of Cigondewah is outlined in Figure 2.

\begin{tabular}{|c|c|c|}
\hline External & $\begin{array}{l}\text { Strengths } \\
\text { 1. Relatively cheaper price } \\
\text { 2. Smooth supply of raw materials and } \\
\text { meet consumer demand } \\
\text { 3. Good reputation in the eyes of } \\
\text { consumers } \\
\text { 4. The range that covers national } \\
\text { market } \\
\text { 5. Availability of local labor }\end{array}$ & $\begin{array}{l}\text { Weaknesses } \\
\text { 1. Not having a cooperative } \\
\text { 2. SMEs do not yet have employees } \\
\text { so that everything is done by } \\
\text { business owners } \\
\text { 3. Only using private sources of } \\
\text { capital } \\
\text { 4. Inadequate infrastructure } \\
\text { 5. Less aggressive marketing } \\
\text { 6. Not having a standardized } \\
\text { product } \\
\text { 7. Lack of product innovation } \\
\text { 8. Not to maximum utilization of } \\
\text { TIU by the entrepreneurs }\end{array}$ \\
\hline $\begin{array}{l}\text { Opportunities } \\
\text { 1. The support of the surrounding } \\
\text { community } \\
\text { 2. The government's policy to } \\
\text { encourage the development of } \\
\text { Industry Center } \\
\text { 3. Availability of internet } \\
\text { technology } \\
\text { 4. Hereditary business culture in } \\
\text { Cigondewah } \\
\text { 5. The opening of broader market } \\
\text { share } \\
\text { 6. Changes in people's lifestyles } \\
\text { 7. Availability of credit offer for } \\
\text { SMEs }\end{array}$ & $\begin{array}{l}\text { SO Strategies: } \\
\text { 1. Optimizing the use of the Internet as } \\
\text { a marketing medium to expand } \\
\text { market share and providing } \\
\text { improved quality of service to } \\
\text { consumers in order to create } \\
\text { consumer loyalty ( } \mathrm{S} 1, \mathrm{~S} 2, \mathrm{~S} 3, \mathrm{~S} 4, \mathrm{~S} 5 \\
-\mathrm{O} 1, \mathrm{O}, \mathrm{O}, \mathrm{O}, \mathrm{O}, \mathrm{O}) \\
\text { 2. Utilizing government policies that } \\
\text { support the development of Industry } \\
\text { Center (S3,S4-O2,O7) }\end{array}$ & $\begin{array}{l}\text { WO Strategies: } \\
\text { 1. Increasing promotional efforts } \\
\text { through various media and } \\
\text { infrastructure improvements by } \\
\text { cooperating with government } \\
\text { agencies (W1, W4, W8 - O1, O2, } \\
\text { O3, O5, O6) } \\
\text { 2. Utilizing capital aid, labor and } \\
\text { local community support for } \\
\text { business development (W2, W3 } \\
\text { - O1, O4) } \\
\text { 3. Forming a cooperative that } \\
\text { serves as a facilitator for SMEs } \\
\text { in the development of industry } \\
\text { centers (W1, W3, W5 - O1, O2, } \\
\text { O7) }\end{array}$ \\
\hline $\begin{array}{l}\text { Threat } \\
\text { 1. Continuous rise of Inflation } \\
\text { 2. Expensive tax rate } \\
\text { 3. Competition of similar industries } \\
\text { 4. Decline in people's purchasing } \\
\text { power }\end{array}$ & $\begin{array}{l}\text { ST Strategies: } \\
\text { 1. Offering competitive prices and } \\
\text { ensuring product availability and } \\
\text { quality of raw materials ( } \mathrm{S} 1, \mathrm{~S} 2, \mathrm{~S} 3 \text {, } \\
\text { S4 - T3, T4) } \\
\text { 2. Improving product quality in order } \\
\text { to compete globally ( } 1, \mathrm{~S} 2, \mathrm{~S} 3, \mathrm{~S} 4 \text { - } \\
\mathrm{T} 1, \mathrm{~T} 2, \mathrm{~T} 3, \mathrm{~T} 4)\end{array}$ & $\begin{array}{l}\text { WT Strategies: } \\
\text { 1. Establishing a good product } \\
\text { standardization in order to } \\
\text { compete in the global market } \\
\text { (W5, W6 - T1, T2, T3, T4) } \\
\text { 2. Improving product innovation by } \\
\text { producing finished textile } \\
\text { products (W6, W7 - T1, T2, T3, } \\
\text { T4) }\end{array}$ \\
\hline
\end{tabular}

Figure 2: SWOT Matrix

Based on table 4, the results of the SWOT matrix analysis resulted in several alternative strategies, among others:

1) Optimizing the use of the Internet as a marketing medium to expand market share and provide improved quality of service to consumers in order to create consumer loyalty (SO-1).

2) Utilizing government policies that support the development of Industry Centers (SO-2).

3) Increasing promotional efforts through various media and infrastructure improvements by cooperating with government agencies (WO-1).

4) Utilizing capital aid, labor and local community support business development (WO-2).

5) Establishing a cooperative that serves as a facilitator for SMEs in the development of Industry centers (WO 3).

6) Offering competitive prices and ensuring product availability and quality of raw materials (ST-1).

7) Improving product quality in order to compete globally (ST-2)
8) Establishing a good product standardization in order to compete in the global market (WT-1)

9) Improving product innovation by producing finished textile products (WT-2)

Based on the results of QSPM matrix, it is identified that the Sum Total Attractiveness Score (STAS), an alternative strategy of WO-1 is "to increase promotional efforts through various media and infrastructure improvements by cooperating with government agencies" with a score of 12.95, the highest score among the other strategic alternatives. The highest STAS shows that the strategy is the best alternative strategy recommended for the development of Textile Industry Center of Cigondewah. The following is the strategy ranking based on QSPM matrix sorted by STAS scores that can be seen in Table 4 . 


\section{International Journal of Science and Research (IJSR) \\ ISSN (Online): 2319-7064}

Index Copernicus Value (2013): 6.14 | Impact Factor (2014): 5.611

Table 4: Strategy Rangking based on QSPM Matrix

\begin{tabular}{|c|c|c|}
\hline No. & Strategy & STAS \\
\hline 1 & $\begin{array}{c}\text { Increasing promotional efforts through various media } \\
\text { and infrastructure improvements by working with } \\
\text { government agencies (WO-1) }\end{array}$ & 12.89 \\
\hline 2 & $\begin{array}{c}\text { Optimize the use of the Internet as a marketing } \\
\text { medium to expand market share and providing } \\
\text { improved quality of service to consumers in order to } \\
\text { create consumer loyalty (SO-1) }\end{array}$ & 12.29 \\
\hline 3 & $\begin{array}{c}\text { Utilizing government policies that support the } \\
\text { development of Industry Centers (SO-2) }\end{array}$ & 9.48 \\
\hline 4 & $\begin{array}{c}\text { Offering competitive prices and ensuring product } \\
\text { availability and quality of raw materials (ST-1) }\end{array}$ & 9.37 \\
\hline 5 & $\begin{array}{c}\text { Forming a cooperative that serves as a facilitator for } \\
\text { SMEs in the development of Industry centers (WO 3) }\end{array}$ & 8,93 \\
\hline 6 & $\begin{array}{c}\text { Improving product quality in order to compete } \\
\text { globally (ST-2) }\end{array}$ & 8.74 \\
\hline 7 & $\begin{array}{c}\text { Improving product innovation by producing finished } \\
\text { textile products (WT-2) }\end{array}$ & 8.7 \\
\hline 8 & $\begin{array}{c}\text { Utilizing capital aid, labor and community support } \\
\text { around business development (WO-2) }\end{array}$ & 8.58 \\
\hline 9 & $\begin{array}{c}\text { Setting a good product standardization in order to } \\
\text { compete in the global market (WT-1) }\end{array}$ & 8.32 \\
\hline
\end{tabular}

\section{Conclusion}

Based on the research that has been done at the Textile Industry Center of Cigondewah, it can be concluded as follows:

1) The analysis of the external environment of the Textile Industry Center of Cigondewah reveals that there are 11 factors consisting of 7 opportunities and 5 threats. The total score of EFE matrix of the Center of Textile Industry Cigondewah is 2.79. This shows that SMEs in the Industry Center of Cigondewah can respond to opportunities and threats that are in the external environment of the industry center quite well.

2) The analysis of the internal environment of the Textile Industry Center of Cigondewah reveals that there are 13 factors consisting of 5 strengths and 8 weaknesses. The total score of IFE matrix of the Textile Industry Center of Cigondewah is 2.08. This shows that SMEs in the Textile Industry Center of Cigondewah is still relatively low in terms of internal where SMEs Textile Industry Center of Cigondewah has not been able to maximize the strengths and has not been able to address weaknesses that exist.

3) The results of SWOT analysis shows several alternative strategies for Textile Industry Center of Cigondewah, among others, as follows:

\section{a) SO Strategies}

- Optimizing the use of the Internet as a marketing medium to expand market share and providing improved quality of service to consumers in order to create customer loyalty.

- Utilizing government policies that support the development of industry center.

b) ST Strategies

- Offering competitive prices and ensuring product availability and quality of raw materials.

- Improving product quality in order to compete globally.

\section{c) WO Strategies}

- Increasing promotional efforts through various media and infrastructure improvements in cooperation with government agencies.

- Utilizing capital aid, labor and local communities to support business development.

- Establishing a cooperative that serves as a facilitator for SMEs in the development of industry centers.

d) WT Strategies

- Setting a good product standardization in order to compete in the global market

- Improving product innovation by producing finished textile products

4) Based on the results of QSPM matrix, it is known that the Sum Total Attractiveness Score (STAS), an alternative strategy of WO-1 is "to increase promotional efforts through various media and infrastructure improvements by cooperating with government agencies" with a score of 12.89 to get the highest score among the alternative strategies. The highest STAS shows that the strategy is the best alternative strategy to be recommended for the development of the Textile Industry Center of Cigondewah.

\section{References}

[1] Anonym. (2013). Jelang KEA 2015, Jabar Terkendala Infrastruktur. [online]. http://diskumkm.jabarprov.go.id/index.php?option=com content\&view=article\&id=187:jelang-kea-2015-jabarterkendala-infrastruktur\&catid $=1$ :laput\& $\quad$ temid $=2 . \quad[3$ March 2015]

[2] Hamid, Edy S., and Susilo, Y. S. (2011). Strategi Pengembangan Usaha Mikro Kecil dan Menengah di Provinsi Daerah Istimewa Yogyakarta. Jurnal Ekonomi Pembangunan, 12(1), 45-55.

[3] Karsidi, Ravik. (2007). Pemberdayaan Masyarakat Untuk Usaha Kecil dan Mikro. Jurnal Penyuluhan, 3(2)

[4] Sriyana, Jaka. (2010). Strategi Pengembangan Usaha Kecil dan Menengah (UKM): Studi Kasus di Kabupaten Bantul. Simposium Nasional 2010: Menuju Purworejo Dinamis dan Kreatif.

[5] Anonym, (2012). Tujuh Sentra Industri Jadi Ciri Bandung 2013. [online]. http://www.pikiranrakyat.com/node/1796101. [19 February 2015]

[6] Anonym. (2012). Sentra Industri Produk Tekstil Cigondewah. [online]. http://sentraindustribandung.com/sentra/industri-produktekstil-cigondewah/. [18 February 2015]

[7] Anonym, (2012). 2013 All Out Optimalkan Tujuh Sentra Industri dan Perdagangan. [online]. http:/ /www.bandung.go.id/index.php/?fa=berita detail\&id=1828. [19 February 2015]

[8] David, Fred R. (2009). Manajemen Strategis. Edition 12. Jakarta: Salemba Empat

[9] Hunger, J. David. and Wheelen, Thomas L. (2003). Manajemen Strategis. Yogyakarta: Andi 


\section{International Journal of Science and Research (IJSR) \\ ISSN (Online): 2319-7064}

Index Copernicus Value (2013): 6.14 | Impact Factor (2014): 5.611

\section{Author Profile}

Taufiqurrahman Baso is Bachelor of Management degree Business Management of Telecomunication and Information from Faculty of Economics and Business, Telkom University in October 2015.

Yuhana Astuti is lecturer in Faculty of Economics and Business, Telkom University. Received S.Si. and S.E. degrees in Padjajaran University, M.T. degree in Bandung Institute of Technology and M.Agr degree in Niigata University 